\title{
Identification of Kiwellin-like Proteins in Fruits by Using In Silico Tools
}

\author{
Ceylan Turkmen ${ }^{1}$ and Levent Cavas ${ }^{1,2,}{ }^{*}$ \\ ${ }^{1}$ Dokuz Eylül University, Graduate School of Natural and Applied Sciences, Department of Biochemistry, \\ ${ }^{2}$ Faculty of Science, Department of Chemistry (Biochemistry Division), Kaynaklar Campus, İzmir, Turkey \\ *Corresponding author: E-mail: levent.cavas@deu.edu.tr \\ Tel: +90232 3018701; Fax: +902324534188
}

Received: 02-01-2019

\begin{abstract}
Identification of allergen proteins by using wet-lab technology is a time-consuming and also costly process. In recent years, thanks to the developments in the field of bioinformatics, it is now possible to estimate the allergen proteins by using in silico tools. In the present study, it is aimed to find kiwellin-like proteins from different fruits samples by using bioinformatics tools. According to the results of the study, six proteins from Corchorus olitorius, Cucumis sativus, Capsicum chinense, Carica papaya, Morus notabilis and Jatropha curcas were defined as the allergens. In conclusion, in silico tools developed under the field of bioinformatics can provide a big contribution to the estimation of unknown allergen proteins in different fruits. Based on the in silico results, physicians can suggest people who have allergenicity to kiwellin not to consume the fruits that contain kiwellin-like proteins.
\end{abstract}

Keywords: Allergen; in silico tools; kiwellin; kiwi; bioinformatics

\section{Introduction}

Fruits are very important for public health. On the other hand, some compounds in fruits can cause allergic reactions. Allergens are the substances that immune system recognizes them as foreign molecules and they cause undesirable reactions in the human body. ${ }^{1,2}$ Many external factors such as dust and pollen may cause allergic reactions ${ }^{1}$ and it is very difficult to stay away from these natural pollutants. In developed countries, the percentage of hy- persensitive people for allergen proteins is around $15-20 .^{3}$ Food allergy within European population was reported as up to $3.2 \%{ }^{3,4,5}$ Generally, allergens are consisted of proteins and it is very important to investigate three-dimentional structures of the allergen proteins to estimate the possible alergic reactions in different populations. ${ }^{6}$ Actually, studying of allergen proteins in wet lab conditions is a time consuming process and it is costly. On the other hand, the database developed for allergen proteins provides big contribution to the understanding of novel aller-

Table 1. Some selected online bioinformatics tools.

\begin{tabular}{lll}
\hline Name of Tool & Web address & Reference \\
\hline AllergenOnline & http://www.allergenonline.org/ & Jin et al 2017 \\
AllerTOP v. 2.0 & http://www.ddg-pharmfac.net/AllerTOP/ & Wold et al., 1993; Dimitrov et al., 2013 \\
AlgPred & http://crdd.osdd.net/raghava/algpred/ & Saha and Raghava, 2006 \\
BIOPEP & http://www.uwm.edu.pl/biochemia/index. & \\
& php/pl/biopep & Minkiewicz et al., 2008 \\
Allergen Nomenclature & http://www.allergen.org/ & Larsen, 2006. \\
BLAST & https://blast.ncbi.nlm.nih.gov/Blast.cgi & Johnson et al., 2007; Boratyn et al., 2013 \\
ExPASy Bioinformatics Resource Portal & https://www.expasy.org/ & Biasini et al., 2014 \\
AllermatchTM & http://www.allermatch.org/ & Codex Alimentarius Commission, 2003. \\
\hline
\end{tabular}


gen proteins and also cross-reactivity. Many tools have so far been developed for estimation of allergen proteins in bioinformatics. ${ }^{7}$ These in silico approaches can estimate if the protein can be considered as an allergen proteins or not. In silico tools can be used for filtering purposes to eliminate the proteins in a long list. Last developments and tools in this field have been reached to reflect the real results. ${ }^{7}$ The properties used in these tools are protein physicochemical parameters, multiple sequence alignment and also 3 dimensional structure comparisons. Especially homology modelling shows superiority to other techniques inasmuch as there is a direct relationship between protein structures and functions. Some selected online tools for prediction of allergen proteins are given in Table 1.

Kiwelin is the protein that constitutes one-third of the total kiwi proteins. ${ }^{8}$ Although there have been many studies on kiwi fruit on its health effects, kiwi is considered as a strong allergen for some people. ${ }^{9,10,11,12}$ The selection of the protein in this paper is associated with increased consumption of kiwi in Turkey because of increasing planting kiwi along the northern coastline of Turkey. ${ }^{13}$ In this study, it was aimed to find proteins which are similar to kiwellin by using bioinformatic tools.

\section{Methods}

\section{1. Sequences and Tools}

In this study, we used database, which is accessible and publicly available on internet. We used WHO/IUIS Allergen Nomenclature Sub-Committee for finding allergen proteins. ${ }^{14,15}$ Basic Local Alignment Search Tool for proteins (BLASTp) search was carried out by BLASTp tool of NCBI. ${ }^{16,17}$ Physicochemical properties of the sequences such as individual amino acid number and percentage, molecular weight, theoretical $\mathrm{pI}$ values, total number of negatively and positively charged residues and instability index were calculated by Protparam tool of Expasy. ${ }^{18}$ Clustal omega was used for multiple sequence alignment. ${ }^{19}$ Swiss-MODEL was used for homology modeling. ${ }^{20}$ Allergenicity estimation was carried out by using AlgPred. ${ }^{21}$ AlgPred estimates the allergen proteins by using the similarity of known epitope. IgE epitope mapping shows the location of epitope in the searched protein sequence. MEME/MAST allergen motifs are also used in Algpred. One another feature in Algpred is based on support vector machine modules which is based on amino acid or dipeptide composition. Algpred tool also allows users to use above mentioned features together that is mentioned as "hybride systems".

\section{2. The Strategy for Identification of Kiwellin-like Proteins}

The sequence of kiwellin kiwi fruit was retrieved from Allergen.org. Then kiwellin-like protein sequences were screened using BLASTp in NCBI website. After BLASTp search, the proteins with high similarity scores were listed in Table 2 . These similar proteins were selected from 10 different and commonly used plants. The kiwellin-like proteins in Table 2 were compared by using following tools: 1) Clustal Omega for multiple sequence alignment, 2) Protparam in Expasy for physicochemical parameters, 3) SWISS-MODEL for homology modelling, 4) AlgPred is used for in silico allergenicity assessment of the proteins.

\section{Results and Discussion}

Kiwellin is one of the well-defined allergen proteins in A.chinensis. However, kiwellin-like proteins in other fruit have not been characterized yet. Developments in the bioinformatics tools can help researchers to find kiwellin-like protein in database easily. In our study, we searched kiwellin-like protein in NCBI database and we found 10 potential proteins which could be considered as candidate allergen proteins (Table 2). Maximum percent identity was found in Barwin-related protein as $95 \%$. On the other hand, minimum identities were observed in the kiwellin like proteins of C. sativus, $P$. persica and C. moschata as $80 \%$. E-values were maximum when $\%$ identity is low and they were minimum when $\%$ identity is high.

Table 2. List of kiwellin-like proteins according to the BLASTp analysis.

\begin{tabular}{|c|c|c|c|c|}
\hline Species & Name of protein (UniProt) & NCBI Reference Sequence & $\begin{array}{c}\text { E-value } \\
\text { for BLAST }\end{array}$ & \% identity \\
\hline Corchorus olitorius & Barwin-related endoglucanase & OMO91533.1 & $5 e-04$ & 95 \\
\hline Vitis vinifera & unnamed protein product, partial (BLASTp) & CBI16343.3 & 0.007 & 85 \\
\hline Cucumis sativus & Uncharacterized protein & KGN46853.1 & 0.16 & 80 \\
\hline Punica granatum & hypothetical protein CDL15_Pgr026889 & OWM73785.1 & 0.012 & 90 \\
\hline Capsicum chinense & Ripening-related protein grip22 & PHU03889.1 & 0.012 & 85 \\
\hline Prunus persica & Receptor-like protein kinase (BLASTp) & XP_020413324.1 & 0.15 & 80 \\
\hline Carica papaya & Kiwellin-like (BLASTp) & XP_021896278.1 & 0.059 & 85 \\
\hline Cucurbita moschata & Kiwellin-like (BLASTp) & XP_022944715.1 & 0.22 & 80 \\
\hline Morus notabilis & Uncharacterized protein & XP_010109489.1 & 0.063 & 85 \\
\hline Jatropha curcas & Uncharacterized protein & KDP44018.1 & 0.064 & 85 \\
\hline
\end{tabular}




\section{1. Multiple Sequence Alignment and Phylogenetic Tree}

We used clustal omega to analyse the similarity of kiwellin-like proteins in this paper. The results were showed in Figure S1.

A first amino acid of kiwellin (I), was same in all candidate proteins except for Prunus persica, Cucumis sativus, Carica papaya. In these species, I was substituted with L. It was very interesting to note that the amino acids at the position of 2,4,6,8,12-14,16,18-20 were same in all studied sequences. It could be said that these regions must have been conserved. $3^{\text {th }}$ amino acid (S) of kiwellin was same in all candidate proteins except for C. chinense and C. olitorius. S is substituted with Q. $17^{\text {th }}$ amino acid (Q) of kiwellin is $\mathrm{R}$ in C. moschata and $\mathrm{E}$ in $\mathrm{V}$. vinifera. The amino acid at the position of 25 is $\mathrm{S}$ in kiwellin of $A$. chinensis, however, it is $\mathrm{C}$ in other studied sequences. Similarly, the amino acid at the position of 27 is $\mathrm{Q}$ in kiwellin of $A$. chinensis, it is $\mathrm{D}$ in all studied samples. A phylogenetic tree was constructed based on multiple sequence alignment by clustal omega (Figure 1). Pairwise sequence alignment of P85261 and P84527 was shown in Figure 2. Phylogenetic tree reveals that the sequences can be classified under three clusters. Kiwellin of $A$. chinensis took place in the first cluster with receptor-like protein kinase of $P$. persica, hypothetical pro-

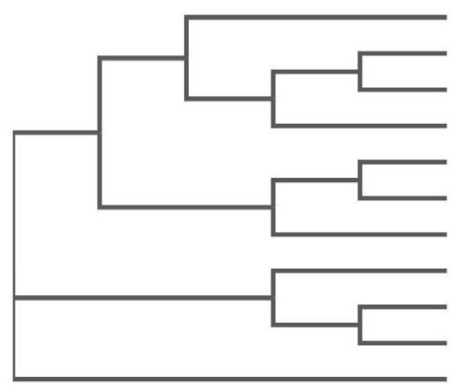

C.chinense 0.20426

P.persica 0.21727

A.chinensis 0.16509

P.granatum 0.16644

C.sativus 0.14168

C.moschata 0.1361

C.papaya 0.16159

V.vinifera 0.17003

C.olitorius 0.11497

M.notabilis 0.11617

J.curcas 0.15858

Figure 1. Phylogenetic tree of the studied sequences. (The name of the proteins in these species were given in Table 2). tein CDL 15_Pgr026889 of $P$. granatum and ripening-related protein grip22 of $C$. chinense. From Figure 1, it could be said that the proteins in $P$. persica, $P$. granatum and $C$. chinense are more close to A. chinensis. These three proteins have not been mentioned in allergen.org yet.

\section{2. ProtParam Results}

Protparam tool is used to characterizate the physicochemical properties of proteins. The tool is available under expasy.ch developed by Swiss Bioinformatics Institute. By using this tool one can obtain the parameters such as amino acid length, molecular weight, theoretical pI values, negatively and positively charged residues, net charges and instability index (Table 3), number and percentage of amino acids (Table 4) in the studied samples.Kiwellin (P85261 (Uniprot), Act c 5 (Allergen.org)) in Actinidia chinensis (Gold Kiwi Fruit) was selected as a model allergen protein in this study. There is also one more kiwellin (P84527 (Uniprot), Act d 5 (allergen.org)) in Actinidia deliciosa in allergen.org. We selected P85261 instead of P84527 to find more matched candidate proteins in BLASTp search. Because the length of P85261 is shorter than that of P84527. Therefore, the protparam parameters of P85261 in Table 3 and 4 are quite different compared to other studied proteins because of its length. On the other hand, there is a problem regarding sequence of P85261. Although it is two separated fragments, it seems like it is consisted of just one fragment. According to Table 3, the maximum and minimum number of amino acids were found in P. persica and A. chinensis, respectively. Theoretical pI value of kiwellin in A. chinensis is 5.98 and it was found as 5.83 (data not shown). From this comparison it could be said that theoretical pI values can not be affected by sequence length. The maximum $\mathrm{pI}$ value was found in C. moschata as 8.54 and minimum value was found from J. curcas as 4.12. In Table 3, the net charges were calculated from the substraction of negatively charged residues from positively charged residues. The net charges of P85261 and P84527 were

CLUSTAL O(1.2.4) multiple sequence alignment

sp|P85261|KIWEL_ACTCH

SP|P84527||KIWEL_ACTDE

Sp|P85261||KIWEL_ACTCH

sp|P'84527||KIWEL_ACTDE

sp|P85261||KIWEL_ACTCH

sp|P84527|KIWEL_ACTDE

Sp|P85261| KIWEL_ACTCH

sp|P84527|KIWEL_ACTDE

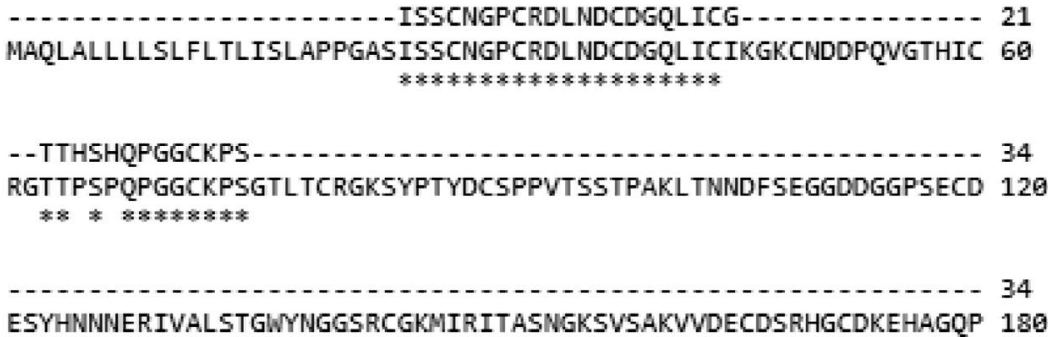

34

PCRNNIVDGSNAVWSALGLDKNVGWDITWSMA 213

Figure 2. Pairwise sequence alignment of P85261 and P84527. 

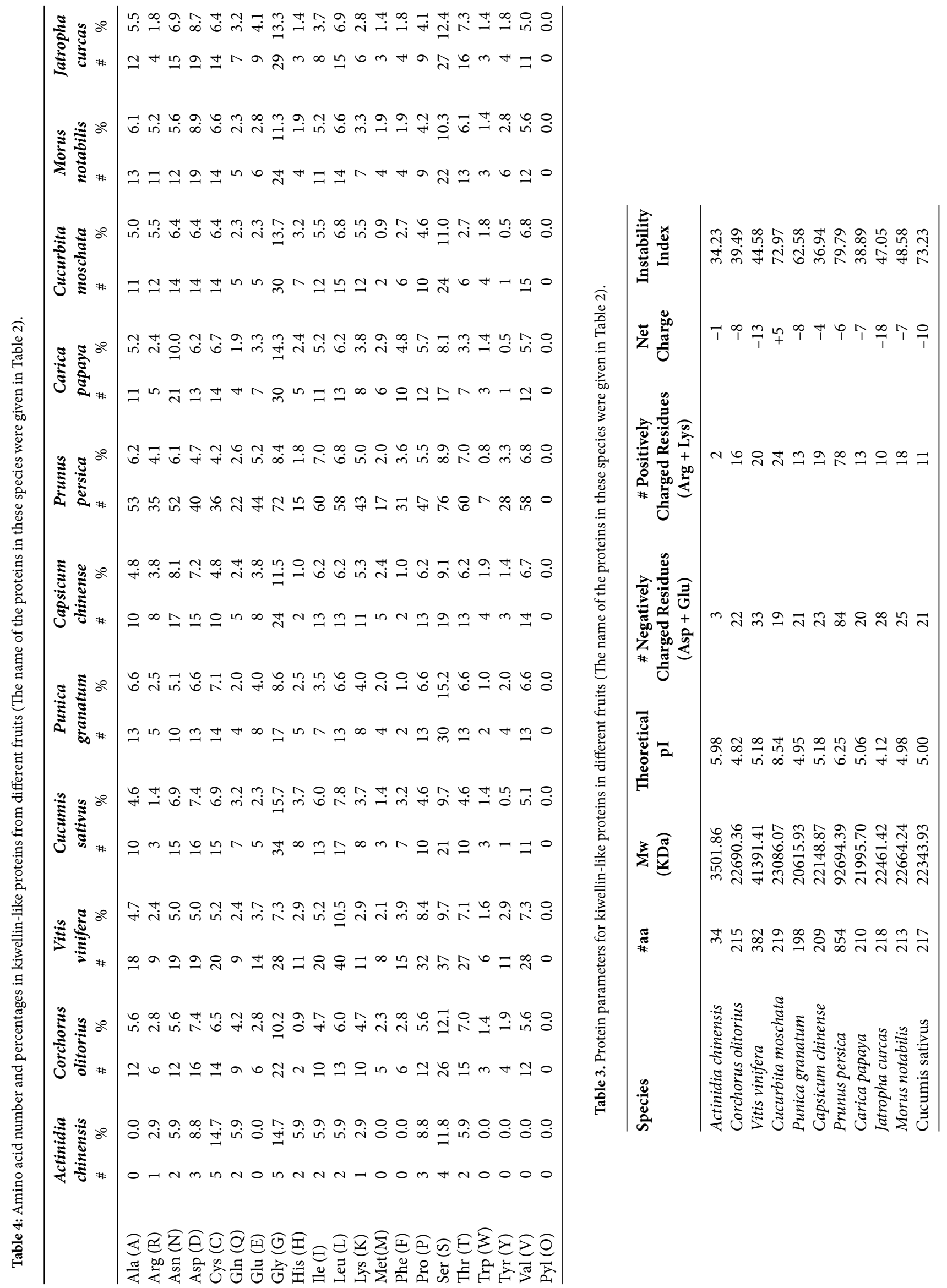


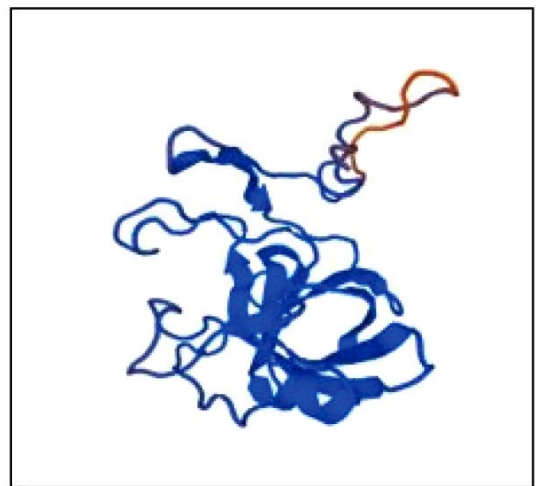

a) Actinidia deliciosa

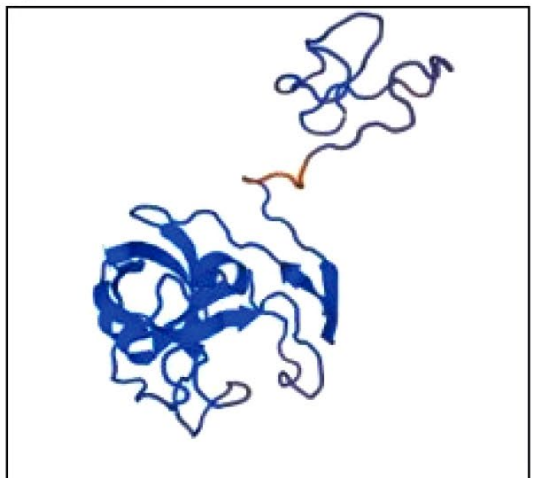

d) Corchorus olitorius

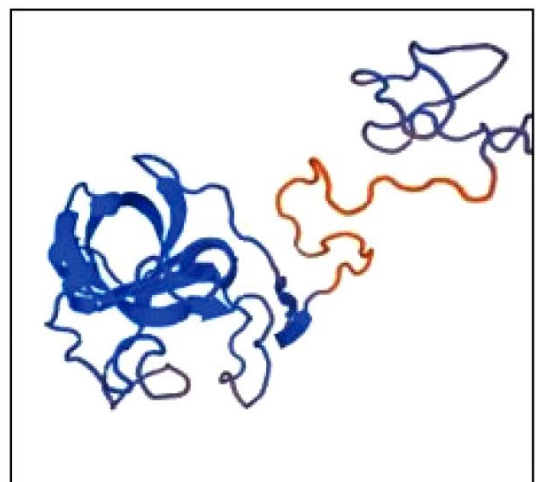

g) Jatropha curcas

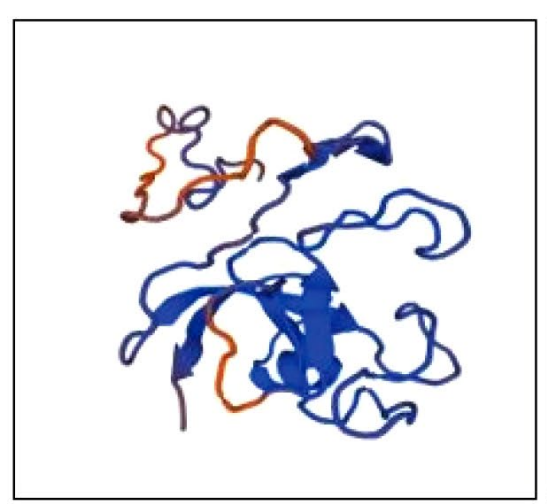

\section{j) Punica granatum}

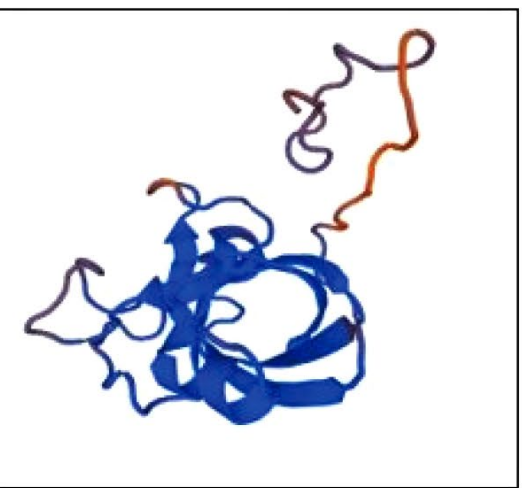

b) Capsicum chinense

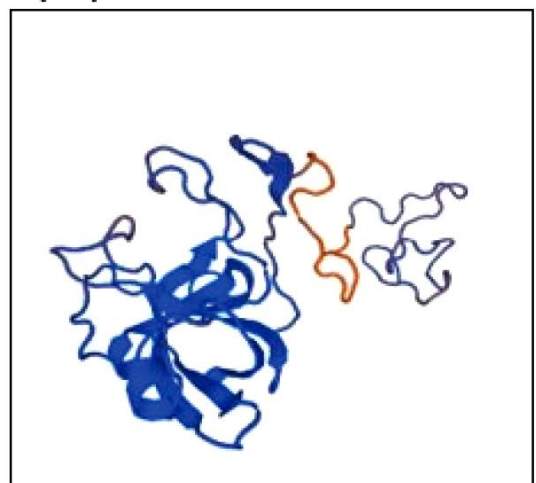

e) Cucumis/sativus

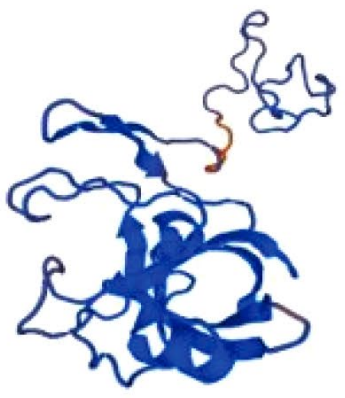

h) Morus notabilis

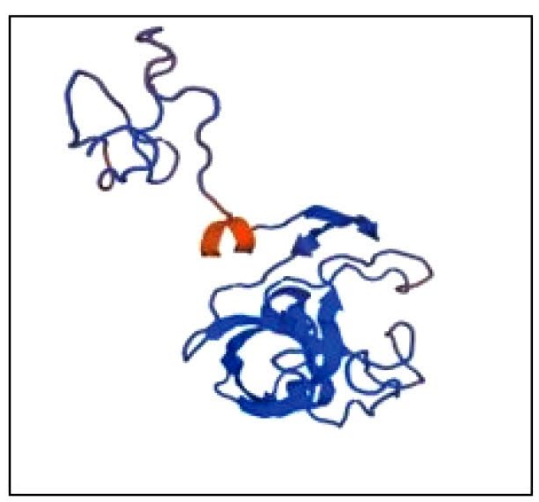

k) Vitis vinifera

Figure 3. 3-Dimensional visualization of each protein by Swiss-MODEL a) Actinidia deliciosa, b) Capsicum chinense, c) Carica papaya, d) Corchorus olitorius, e) Cucumis sativus, $f$ ) Cucurbita moschata, $g$ ) Jatropha curcas, $h$ ) Morus notabilis, i) Prunus persica, $j$ ) Punica granatum, $k$ )Vitis vinifera (The name of the proteins in these species were given in Table 2). 
found as -1 and -4 , respectively, which show that kiwellin is a negatively charged protein. Only positive value was observed in $C$. moschata as +5 . The highest and lowest instability index were found in the proteins of $P$. persica and $A$. chinensis. The correlation test was carried out for the data in Table 3. But no meaningful correlation was found among the data. When the amino acid numbers and percentages were compared, it was found that glycine and serin were dominant amino acids in the sequences apart from the protein of $V$. vinifera.

\section{3. The Homology Modelling}

The homology modelling was carried by using Swiss-MODEL. 3-D structures of proteins are essential and important for understanding biological systems. 3-D homology models also reveal that the kiwellin-like proteins in these species may exhibit similar allergenicity inhuman. The created 3-D structures were given in Figure 3. Except for the proteins of $P$. granatum, $P$. persica and $V$. vinifera, the proteins include similar barrel-like structure formed by beta-sheets. The pore-forming property of the kiwellin might be associated with these structures. From these homology modelling results, one can estimate the allergenicity of the proteins by comparing the 3-D structures since there is a direct relationship between function and structures of the proteins. Because there is a direct relationship between structure and function in proteins. It is important to note that the structure of kiwellin belongs to P84527 in Figure 3 due to the sequence length of P85261 is shorter that P84527.

\section{4. AlgPred}

There are three types prediction algorithms to estimate allergenity: i) Mapping of IgE epitopes and PID, ii) support vector machine modul based on amino acid composition and iii) support vector machine modul based on dipeptide composition. The results of these algorithms are given in Table 5. The mapping of IgE epitopes and PID estimated that none of 10 different proteins were identified as potential allergen. According to SVM based on amino acid resuls all protein except $V$. vinifera are showed allergen. Considering the SVM based on dipeptide composition resuls, six protein C. olitorus, C. sativus, C. chinense, C. papaya, M. notabilis and J. curcas were identified allergen. There are six proteins (C. olitorus, C. sativus, C. chinense, C. papaya, M. notabilis, J. curcas) in which the two SVM algorithms give positive results.

It should be noted that \% identity might not be used as an important criteria to evaluate if a protein is allergen or not.When we compare all results, we see that only 6 of 10 potential allergens are classified as an allergen. When BLASTp results were examined, the proteins in C. olitus (95\%) and C. sativus (\%80) were classified as allergen proteins. However, even if the protein in P. granatum has high similarity (90\%), it was not identified as an alergen protein.From these results, it could be said that the similarity index can not be used as an criteria. When Swiss-MODEL results are considered, 3-D structures are different. AlgPred contains diffent algorithms to evalute the submitted protein sequences. ${ }^{21}$ Three of them are mapping of IgE epitopesand PID, support vectore machine module based on amino acid and dipeptide compositions. So the methods are based on different algorithms. Six proteins in this study were evaluated as alergen proteins inasmuch as they were identified by support vectore machine module based on amino acid and dipeptide compositions (Table 5).

\section{Conclusions}

The aim of the paper is to find kiwellin-like proteins by using allergen based in silico tools. Based on the results of the study, it might be said that identified kiwellin-like proteins in this study might show similar allergenity in

Table 5: AlgPred analysis of diffirent allergens in fruits (The name of the proteins in these species were given in Table 2).

\begin{tabular}{|c|c|c|c|c|c|c|c|c|c|}
\hline \multirow{2}{*}{$\begin{array}{l}\text { AlgPred } \\
\text { Parameters } \\
\text { Species }\end{array}$} & \multirow{2}{*}{$\begin{array}{l}\text { Mapping of } \\
\text { IgE epitopes } \\
\text { and PID }\end{array}$} & \multicolumn{4}{|c|}{$\begin{array}{l}\text { SVM module based on amino acid } \\
\text { Composition }\end{array}$} & \multicolumn{4}{|c|}{$\begin{array}{l}\text { SVM module based on dipeptide } \\
\text { Composition }\end{array}$} \\
\hline & & $\begin{array}{c}\text { Allergen } \\
\text { prediction }\end{array}$ & Score & $\begin{array}{l}\text { Positive } \\
\text { predictive } \\
\text { value }(\%)\end{array}$ & $\begin{array}{l}\text { Negative } \\
\text { predictive } \\
\text { value }(\%)\end{array}$ & $\begin{array}{l}\text { Allergen } \\
\text { predictive }\end{array}$ & Score & $\begin{array}{l}\text { Positive } \\
\text { prediction } \\
\text { value }(\%)\end{array}$ & $\begin{array}{l}\text { Negative } \\
\text { predictive } \\
\text { value (\%) }\end{array}$ \\
\hline Corchorus olitorius & $\mathrm{X}$ & $\sqrt{ }$ & 0.43526052 & 81.83 & 74.03 & $\sqrt{ }$ & -0.048627 & 63.10 & 85.56 \\
\hline Vitis vinifera & $\mathrm{X}$ & $\mathrm{X}$ & -0.74099846 & 22.82 & 92.94 & $\mathrm{X}$ & -0.676397 & 13.26 & 74.19 \\
\hline Cucumis sativus & $\mathrm{X}$ & $\sqrt{ }$ & 0.91145594 & 85.64 & 67.96 & $\sqrt{ }$ & 0.004279 & 74.14 & 79.04 \\
\hline Punica granatum & $\mathrm{X}$ & $\sqrt{ }$ & -0.14027725 & 64.55 & 86.61 & $\mathrm{X}$ & -0.643383 & 13.26 & 74.19 \\
\hline Capsicum chinense & $\mathrm{X}$ & $\sqrt{ }$ & 0.83191078 & 85.64 & 67.96 & $\sqrt{ }$ & -0.034468 & 63.10 & 85.56 \\
\hline Prunus persica & $\mathrm{X}$ & $\sqrt{ }$ & 0.37866622 & 74.81 & 76.94 & $\mathrm{X}$ & -0.652229 & 13.26 & 74.19 \\
\hline Carica papaya & $\mathrm{X}$ & $\sqrt{ }$ & 0.77608681 & 87.05 & 71.53 & $\sqrt{ }$ & 0.320983 & 85.88 & 72.01 \\
\hline Cucurbita moschata & $\mathrm{X}$ & $\sqrt{ }$ & -0.13002118 & 64.55 & 86.61 & $\mathrm{X}$ & -0.256085 & 39.40 & 89.34 \\
\hline Morus notabilis & $\mathrm{X}$ & $\sqrt{ }$ & 0.25337214 & 74.81 & 76.94 & $\sqrt{ }$ & -0.028054 & 63.10 & 85.56 \\
\hline Jatropha curcas & $\mathrm{X}$ & $\sqrt{ }$ & 0.78994643 & 87.05 & 71.53 & $\sqrt{ }$ & 0.304532 & 85.88 & 72.01 \\
\hline
\end{tabular}


people who have kiwellin allergenity. The identification of an unknown protein in a fruit sample by using in silico tools is so easier to estimate its allergenicity compared to wet-lab methodology. This strategy can reduce the cost of medicine and/or therapy costs spent for allergenicity. Therefore, there is a great need for development of novel allergenicity tools with better accuracy. Kiwi is an important and highly consumed fruit because of its rich ingredients such as vitamins and antioxidant molecules. Natural production place of kiwi is China. On the other hand, kiwi is also produced in Italy, New Zealand, Iran and Chile. According to FAOSTAT, total production of kiwi is $4,274,840$ ton. ${ }^{22}$ Although kiwi is known as a healthy fruit, it has 13 allergen proteins in it, according to allergen.org. Kiwi has also been started to produce in different country. For example, kiwi trees have been planted in the northern part of Turkey and now the production are significantly increasing. Since some people have not consumed this fruit previously, people should be informed about the possible allergenity of the allergen proteins of kiwi. In the present study, 10 kiwellin-like proteins have been studied in 10 different plants based on the similarities. It is very important to note that these proteins have still not been taken place in allergen.org. Many scientific studies have been published on kiwi. Tamburrini et al. ${ }^{8}$ purified kiwellin and defined it as an allergen protein. They also mentioned that kiwellin is one third of the total protein of kiwi fruit. In their study, it is selected because of high abundance in kiwi fruit compared to other allergen proteins. They proved its allergenity by using Scin Prick test, western blot, spesific IgE and total IgE tests. Tuppo et al. ${ }^{23}$ also showed that kissper part of kiwellin is a proteolysis-resistant protein and also it constitutes pore-forming in lipid membrane of cell. $\mathrm{pH}$ dependent and thionine containing Kissper also shows its function in ion-channels. These functions cause allergenity in human. Ciardiello et al. ${ }^{24}$ identified two domains in kiwellin. First one is known as kissper consisted of first 39 amino acids and 6 of them is Cys. Kissper is located in the $\mathrm{N}$-terminal. Second domain is known as KiTH and located in C-terminal. The residue number of this location is between 40-189. 8 Cys were also reported for this residue. Ciardiello et al. ${ }^{24}$ mentioned that kiwellin based ion channel distruption can be associated with cystic fibrosis. Offerman et al. ${ }^{25}$ reported X-crystallography of kiwellin protein in A. deliciosa (Act d 5). Pore forming structure of kiwellin was also explained by Offerman et al. ${ }^{25}$. Hamiaux et al. ${ }^{26}$ investigated crystal structure of kiwellin and they found that there is a binding region on the surface of kiwellin for endogenous ligands. Uberti et al. ${ }^{27}$ studied 13 allergen proteins in kiwi. They defined 3 of them as major allergen proteins (Act d 1, Act d 2, Act d 6). Act d 5 and Act $\mathrm{d}$ 8/11 were defined as minor allergen proteins by Uberti et al. ${ }^{27}$ Jenkins et al. ${ }^{28}$ analysed the plant genomes to study allergen proteins. It is reported that $65 \%$ of the food allergens are originated from 4 different protein family. According to an interesting paper by Ciacci et al. ${ }^{29}$ they explained antioxidant and anti inflammatory effects of kissper peptide. In this study, 6 proteins were defined as allergens. by using in silico tools in 10 different fruits. From the outputs of this paper and also published papers in this field, it is most likely to be said that in silico tools will be of great importance in the life sciences. $., 7,28,30,31$

In conclusion, kiwellin like proteins can be existed in not only kiwi but also in different fruits. By using in silico tools, it is more easier to define possible allergen proteins. Since in silico tools have recently been developed, more input will be released in near future. The outputs from in silico based investigations will most likely decrease number of allergen based disorders. More scientific researches will be needed for development of new in silico tools and also application them to find allergen proteins in foods. Developments in the field of artificial intelligence will most likely to increase the quality of in silico tools in near future.

\section{References}

1. F. Ferreira, T. Hawranek, P. Gruber, N. Wopfner, A. Mari, Allergy. 2004, 59(3), 243-267.

DOI:10.1046/j.1398-9995.2003.00407.x

2. T. Karluss, G. Bannon, S. Hefle, C. Herouet, M. Holsapple, G. Ladics, S. MacIntosh, L. Privalle, Toxicol. Sci. 2005, 88(2), 307-310. DOI:10.1093/toxsci/kfi277

3. Å. K. Björklund, D. Soeria-Atmadja, A. Zorzet, U. Hammerling, M.G. Gustafsson, Bioinformatics. 2004, 21(1), 39-50. DOI:10.1093/bioinformatics/bth477

4. J. J. N. Jansen, A. F. Kardinaal, G. Huijbers, B. J. Vlieg-Boerstra, B. P. Martens, T. Ockhuizen, J. Allergy Clin. Immunol. 1994, 93(2), 446-456. DOI:10.1016/0091-6749(94)90353-0

5. G. Kanny, D. A. Moneret-Vautrin, J. Flabbee, E. Beaudouin, M. Morisset, F. Thevenin, J. Allergy Clin. Immunol. 2001, 108(1), 133-140. DOI:10.1067/mai.2001.116427

6. J. Cui, L. Y. Han, H. Li, C. Y. Ung, Z. Q. Tang, C. J. Zheng, Z. W. Cao, Y. Z. Chen, Mol. Immunol. 2007, 44(4), 514-520.

DOI:10.1016/j.molimm.2006.02.010

7. M. Hayes, P. Rougé, A. Barre, C. Herouet-Guicheney, P. Rouge, E. L. Roggen, Drug Discov. Today Dis. Models. 2015. 17, 3-11. DOI:10.1016/j.ddmod.2016.06.001

8. M. Tamburrini, I. Cerasuolo, V. Carratore, A. A. Stanziola, S. Zofra, L. Romano, L. Camardella, M. A. Ciardiello, Protein J. Vol. 2005, 24, 7-8. DOI:10.1007/s10930-005-7638-7

9. N. Motohashi, Y. Shirataki, M. Kawase, S. Tani, H. Sakagami, K. Satoh, T. Kurihara, H. Nakashima, I. Mucsi, A. Varga, J. Molna, J. Ethnopharmacol. 2002, 81, 357/364.

DOI:10.1016/S0378-8741(02)00125-3

10. M. Gavrović-Jankulović, T. Ćirković, O. Vučković, M. Atanasković-Marković, A. Petersen, G. Gojgić, L. Burazer, R. M. Jankov, J. Allergy Clin. Immunol. 2002, 110(5), 805-810. DOI:10.1067/mai.2002.128947

11. A. Collins, V. Harrington, J. Drew, R. Melvin, Carcinogenesis. 2003, 24(3), 511-515. DOI:10.1093/carcin/24.3.511 
12. J. S. Lucas, S. A. Lewis, J. H. Hourihane, Pediatr Allergy Immunol. 2003, 14, 420-428. DOI:10.1046/j.0905-6157.2003.00095.x

13. A. Çavuş, Atatürk Üniversitesi Sosyal Bilimler Dergisi. 2016, 20, 225-241.

14. M. D. Chapman, A. Poms, H. Breiteneder, F. Ferreira, J. Allergy Clin. Immunol. 2007, 119, 414-20.

DOI:10.1016/j.jaci.2006.11.001

15. J. N. Larsen, Allergen nomenclature: a need for the scientific community. Arbeitenausdem Paul-Ehrlich-Institut (Bundesamt fur Sera und Impfstoffe) zu Frankfurt aM, 2006, (95), 5-9.

16. G. M. Boratyn, C. Camacho, P. S. Cooper, G. Coulouris, A. Fong, N. Ma, T. L. Madden, W. T. Matten, S. D. McGinnis, Y. Merezhuk, Y. Raytselis, E. W. Sayers, T. Tao, J. Ye, I. Zaretskaya, Nucleic Acids Res. 2013, 41, W29-W33.

DOI:10.1093/nar/gkt282

17. M. Johnson, I. Zaretskaya, Y. Raytselis, Y. Merezhuk, S. McGinnis, T. L. Madden, Nucleic Acids Res. 2008, 36, W5W9. DOI:10.1093/nar/gkn201

18. E. Gasteiger, C. Hoogland, A. Gattiker, M. R. Wilkins, R. D. Appel, A. Bairoch, A. Protein identification and analysis tools on the ExPASy server. In The proteomics protocols handbook, 2005, 571-607. DOI:10.1385/1-59259-890-0:571

19. F. Sievers, A. Wilm, D. G. Dineen, T. J. Gibson, K. Karplus, W. Li, R. Lopez, H. McWilliam, M. Remmert, J. Söding, J. D. Thompson, D. G. Higgins, Mol. Syst. Biol. 2011, 7:539.

DOI:10.1038/msb.2011.75

20. M. Biasini, S. Bienert, A. Waterhouse, K. Arnold, G. Studer, T. Schmidt, F. Kiefer, T. G. Cassarino, M. Bertoni, L. Bordoli, T. Schwede, Nucleic Acids Res. 2014, 42, W252-W258. DOI:10.1093/nar/gku340

21. S. Saha, and G. P. S. Raghava, Nucleic Acids Res. 2006, 34, W202-W209. DOI:10.1093/nar/gkl343
22. FAOSTAT, Kiwifruit production in 2016; Crops/World Regions/Production Quantity from pick lists. UN Food and Agriculture Organization, Statistics Division DOI: http://www. fao.org/faostat/en/\#data/QV (Retrieved February 20, 2018).

23. L. Tuppo, I. Giangrieco, P. Palazzo, M. L. Bernardi, E. Scala, V. Carratore, M. Tamburrini, A. Mari, M. A. Ciardiello, J. Agric. Food Chem. 2008, 56(10), 3812-3817. DOI:10.1021/jf703620m

24. M. A. Ciardiello, D. Meleleo, G. Saviano, R. Crescenzo, V. Carratore, L. Camardella, E. Gallucci, S. Micelli, T. Tancredi, D. Picone, M. Tamburrini, J. Pept. Sci. 2008, 14(6), 742-754. DOI:10.1002/psc.992

25. L. R. Offermann, I. Giangrieco, M. L. Perdue, S. Zuzzi, M. Santoro, M. Tamburrini, J. D. Cosgrove, A. Mari, M. A. Ciardiello, M. Chruszcz, J. Agric. Food Chem. 2015, 63(29), 65676576. DOI:10.1021/acs.jafc.5b02159

26. C. Hamiaux, R. Maddumage, M. J. Middleditch, R. Prakash, D. A. Brummell, E. N. Baker, R. G. Atkinson, J.struct. biol. 2014, 187(3), 276-281. DOI:10.1016/j.jsb.2014.07.005

27. F. Uberti, E. Peñas, Y. Manzoni, C. Lorenzo, C. Ballabio, A. Fiocchi, L. Terracciano, P. Restani, Pediatr. Allergy Immunol. 2015, 26(2), 139-144. DOI:10.1111/pai.12345

28. J. A. Jenkins, S. Griffiths-Jones, P. R. Shewry, H. Breiteneder, E. C. Mills, J. Allergy Clin. Immunol. 2005, 115(1), 163-170. DOI:10.1016/j.jaci.2004.10.026

29. C. Ciacci, I. Russo, C. Bucci, P. Iovino, L. Pellegrini, I. Giangrieco, M. A. Ciardiello, Clin. Exp. Allergy. 2014, 175(3), 476-484. DOI:10.1111/cei.12229

30. T. C. Tomaš, M. Moškon, M. Mraz, Rozman, D, Acta Chim. Slov. 2018, 65, 253-265. DOI:10.17344/acsi.2015.1505

31. S. Pleško, H. Volk, M. Lukšič, Č. Podlipnik, Acta Chim. Slov. 2015, 62(3), 555-564.

\section{Povzetek}

Identifikacija alergenih beljakovin $\mathrm{z}$ uporabo tako imenovane wet-lab tehnologije je zamuden in tudi drag proces. $\mathrm{V}$ zadnjih letih, zahvaljujoč razvoju na področju bioinformatike, je zdaj mogoče oceniti alergene beljakovine $\mathrm{z}$ uporabo računskih orodij. V tej študiji je bil cilj, da bi z uporabo bioinformatskih orodij našli kivelinu podobne beljakovine iz različnih vzorcev sadja. Glede na rezultate študije je bilo šest beljakovin iz Corchorus olitorius, Cucumis sativus, Capsicum chinense, Carica Papaya, Morus notabilis in Jatropha curcas opredeljenih kot alergeni. Skratka, računska orodja, razvita na področju bioinformatike, lahko zagotovijo velik prispevek k oceni neznanih beljakovinskih alergenov v različnih plodovih. Na podlagi teh in silico rezultatov zdravniki lahko priporočajo ljudem, ki so alergični na kivelin, da ne uživajo sadja, ki vsebuje kivelinu podobne beljakovine.

Except when otherwise noted, articles in this journal are published under the terms and conditions of the Creative Commons Attribution 4.0 International License 